\title{
Pengaruh Jenis Biochar terhadap Pertumbuhan dan Hasil Beberapa Jenis Cover Crop dalam Tumpang Sari dengan Jagung Varietas Lokal (Zea Mays.L)
}

Antonius Th. Metboki ${ }^{\mathrm{a}}$

${ }^{a}$ Fakultas Pertanian, Universitas Timor, Kefamenanu, TTU - NTT, Indonesia, email: tonimetboki@gmail.com

\section{Article Info}

Article history:

Received in revised form 2 Juli 2019

Accepted 18 Juli 2019

$D O I:$

\section{Keywords:}

Cover crop

Biochar

Intercropping
Received 13 Juni 2019

https://doi.org/10.32938/sc.v4i02.745

\begin{abstract}
Abstrak
Penelitian ini bertujuan untuk mempelajari beberapa jenis biochar yang mempengaruhi pertumbuhan dan hasil tanaman Cover crop pada tumpang sari dengan tanaman Jagung lokal kuning dan untuk mengkaji efek jenis Cover crop terhadap kadar lengas dan berat volume tanah. Penelitian ini dilaksanakan pada pada bulan Januari-Juli 2018 di kebun percobaan Fakultas Pertanian (belakang Perpustakaan Universitas Timor). Penelitian ini menggunakan rancangan petak beralur (Strip Plot Design). Faktor pertama adalah jenis cover crop (C) terdiri dari 3 aras, Kacang Arbila (Phaseolus lunatus) $\left(\mathrm{C}_{1}\right)$, Kacang Nipe (Mucuna pruriens) $\left(\mathrm{C}_{2}\right)$, dan Kacang Nasi (Vigna anggularis L.) $\left(\mathrm{C}_{3}\right)$. Faktor kedua adalah jenis biochar $(\mathrm{B})$ yang terdiri dari 4 (empat) aras yakni tanpa biochar $\left(\mathrm{B}_{0}\right)$, serbuk gergaji $\left(\mathrm{B}_{1}\right)$, sekam padi $\left(\mathrm{B}_{2}\right)$, kerinyuh $\left(\mathrm{B}_{3}\right)$. Hasil penelitian menunjukkan tidak adanya interaksi pengamatan antara legume cover crop dan jenis biochar. Cover crop M. pruriens memiliki luas penutupan tanah tertinggi dan memberikan suhu tanah terendah dan dapat mempertahankan kadar lengas tanah. Produktivitas cover crop $V$. angularis memberikan produktivitas hasil terbaik sedangkan $M$. pruriens belum berproduksi namun memiliki luas penutupan tanah yang besar dan ketebalan yang tinggi yang mana sangat baik digunakan sebagai tanaman penutup tanah.
\end{abstract}

\section{Pendahuluan}

Tumpang sari (Intercropping) merupakan suatu usaha untuk menanam beberapa jenis tanaman pada lahan dalam waktu yang sama misalnya Jagung, Kacang-Kacangan dan Ubi-Ubian (Setiawan, 2009). Beberapa keuntungan pada pola tumpangsari yakni terjadi peningkatan efisiensi tenaga kerja, pemanfaatan lahan maupun penyerapan sinar matahari, populasi tanaman dapa diatur sesuai yang dikehendaki, dalam satu areal diperoleh produksi lebih dari satu komoditas tetapi mempunyai peluang mendapatkan hasil apabila satu jenis tanaman yang diusahakan gagal dan kombinasi beberapa jenis tanaman, dapat menciptakan beberapa jenis tanaman, menciptakan stabilitas biologis sehingga dapat menekan serangan hama dan penyakit serta mempertahankan kelestarian sumber daya lahan dalam hal ini kesuburan tanah. Jagung merupakan tanaman Serelia yang termasuk bahan pangan penting karena merupakan sumber karbohidrat kedua setelah beras. Sebagai salah satu sumber bahan pangan Jagung telah menjadi komoditas utama setelah beras (Purwono dkk., 2011). Jagung juga sebagai bahan industri dan pakan ternak. Jagung memiliki sumber karbohidrat yang kompleks, dan sejumlah zat gizi lainnya seperti Vitamin B dan C, Karoten, Kalium, Zat besi, Magnesium, Fosfor, Omega 6 dan Lemak tak jenuh yang dapat membantu menurunkan kolesterol.

Data BPS NTT (2015) menunjukkan pada periode 2013-2014 luas panen Jagung di NTT menurun dari 270.394 ha menjadi 250.725 ha yang mana produksinya juga turut menurun dari 707.642 ton/ha menjadi 647.108 ton/ha dengan nilai produktivitas Jagung dari $26.17 \mathrm{kw} / \mathrm{ha}$ menjadi $25.18 \mathrm{kw} / \mathrm{ha}$. Maka dari itu untuk meningkatkan kembali jumlah produksi dan produktivitas Jagung di daerah Nusa Tenggara Timur (NTT) perlu adanya perhatian khusus dan juga perluasan areal tanam. Penyebab terjadinya perubahan produksi Jagung yang sangat besar di wilayah kabupaten Timor Tengah Utara diakibatkan musim kemarau yang lebih panjang yaitu, 8 bulan (April-November) sedangkan musim hujan yang pendek hanya berkisar 4 bulan (Desember-Maret). Upaya untuk meningkatkan kembali produksi dan produktivitas Jagung pada saat musim kemarau dapat dilakukan melalui pengolahan tanah yang tepat seperti pemberian pupuk organik, penambahan biochar sebagai bahan pembenah tanah dan penggunaan tanaman penutup tanah (Cover crop) dalam menekan gulma dan menjaga pelepasan air dari tanah.

Pengembalian $\mathrm{C}$ organik dalam tanah juga merupakan salah satu upaya peningkatan kualitas dan kesehatan tanah dalam pertanian berkelanjutan. Biochar merupakan senyawa karbon yang relatif stabil dalam jangka waktu panjang dan memiliki afinitas yang tinggi terhadap kation. Karakteristik khas ini yang menyebabkan biochar akan sangat bermanfaat untuk mengurangi laju degradasi tanah. Biochar juga dapat meningkatkan ketersediaan hara dalam jangka panjang (Glaser dkk., 2002 ; Lehmann, 2007; Lehmann dan Joshep, 2009; Major dkk., 2009). Terdapat beberapa manfaat dengan menambahkan biochar ke dalam tanah yaitu meningkatkan pertumbuhan tanaman, menekan emisi metana, mengurangi emisi NO (perkiraan 50\%), mengurangi kebutuhan pupuk (perkiraan 10\%), mengurangi pencucian hara, menyimpan karbon dalam jangka panjang secara stabil, mengurangi kemasaman tanah, meningkatkan $\mathrm{pH}$ tanah, mengurangi keracunan aluminium, meningkatkan agregsi tanah, meningkatkan karakteristik pemeliharaan air tanah, meningkatkan kemampuan tanah menyediakan $\mathrm{Ca}, \mathrm{Mg}, \mathrm{P}$ dan $\mathrm{K}$, meningkatkan respirasi mikroba tanah, meningkatkan biomassa mikroba tanah, menstimulasi simbiosis fiksasi nitrogen pada legum, meningkatkan fungi mikoriza arbuscular dan meningkatkan kapasitas tukar kation.

Cover crop merupakan tanaman yang mempunyai kemampuan untuk menghasilkan bahan organik tinggi sehingga dapat membantu meningkatkan kesuburan tanah, kemampuan memfiksasi nitrogen dari udara oleh leguminosa dapat membantu meningkatkan suplai hara terutama nitrogen bagi tanaman yang disampingnya. Cover crop dari jenis leguminosa dapat ditanam sebagai tanaman penutup lahan atau tanah mempunyai fungsi untuk konservasi tanah dan air. Upaya perbaikan lahan pertanian dengan penambahan biochar dan juga adanya upaya penggunaan tanaman penutup tanah pada pola tumpang sari dengan tanaman Jagung menjadi menarik untuk dikaji melalui penelitian
"Pengaruh Jenis Biochar Terhadap Pertumbuhan dan Hasil Beberapa Jenis Cover Crop dalam Tumpang Sari dengan Jagung Lokal Kuning (Zea mays L)". Penelitian ini bertujuan untuk mempelajari jenis biochar yang paling mempengaruhi pertumbuhan dan hasil tanaman Cover crop serta mengkaji efek jenis Cover crop terhadap kadar lengas dan berat volume tanah.

\section{Metode}

Penelitian ini dilaksanakan pada bulan Januari-Juli 2018 di kebun percobaan Fakultas Pertanian, Universitas Timor Kelurahan Sasi Kota Kefamenanu Kabupaten Timor Tengah Utara, Propinsi Nusa Tenggara Timur. Bahan dan alat penelitian yang digunakan dalam penelitian ini adalah Jagung varietas lokal kuning dan 3 jenis cover crop yakni: Kacang Arbila (Phaseolus lunatus), Kacang Bengis (Mucuna bracteata), dan Kacang Nasi (V. angularis L). Alat yang digunakan antara lain: Timbangan analitik, Jangka sorong, Kontiki, Timbangan duduk, Oven, Termometer suhu tanah, Lux meter, Termometer Hygrometer, pH meter, Lampu spritus, Gelas ukur, Pemindai (Scanner), Aerator, Terpal, Gembor, Sprayer.

Penelitian ini menggunakan rancangan petak beralur (Strip Plot Design) $3 \times 4$ yang diulang tiga kali. Faktor pertama adalah jenis Cover crop $(\mathrm{C})$ terdiri dari 3 aras yaitu: Kacang Arbila (P. lunatus) (C1), Kacang Bengis $(M$. pruriens) (C2), Kacang Nasi (V. anggularis L.) (C3). Faktor kedua adalah jenis biochar (B) yang terdiri dari 4 (empat) aras yaitu: tanpa biochar (B0), serbuk gergaji (B1), sekam Padi (B2), Kerinyuh (B3). Kombinasi perlakuannya adalah: C1B0, C1B1, C1B2, C1B3, C2B0, C2B1, C2B2, C2B3, C3B0, C3B1, C3B2, $\mathrm{C} 3 \mathrm{~B} 3$ masing-masing diulang 3 kali sehingga terdapat 36 satuan percobaan.

Parameter pengamatan meliputi: Suhu tanah, Kadar lengas tanah, Berat volume tanah, Tinggi tanaman cover crop, Diameter batang tanaman cover crop, Jumlah daun tanaman cover crop, Tebal penutupan tanaman cover crop, Luas penutupan tanaman cover crop, Jumlah biji per polong, Panjang polong, Jumlah total polong, Berat biji total, Berat 100 biji ton per hektar, Jumlah bintil akar, Bintil akar efektif, Berat basah brangkasan per tanaman, Berat kering brangkasan per tanaman, Berat kering brangkasan per hektar, Berat segar brangkasan per hektar, Total bintil akar per hektar, Total bintil akar efektif per hektar, Luas daun.

Data hasil pengamatan dianalisis dengan menggunakan analisis sidik ragam (Anova) Rancangan Petak Beralur (Strip Plot Design). Untuk mengetahui ada tidaknya interaksi antara faktor perlakuan, rata-rata perlakuan selanjutnya diuji lanjut dengan menggunakan Duncan Multiple Range Test (DMRT) dengan tingkat signifikasi sebesar $5 \%$, sesuai petunjuk Gomez and Gomez (2010). analisis data menggunakan program SAS 9.1.

\section{Hasil dan Pembahasan \\ 3.1 Hasil}

Suhu Tanah

Suhu tanah mempengaruhi berbagai proses dalam tanah seperti aktivitas organisme, dekomposisi bahan organik, reaksi kimia tanah, dan pelapukan batuan (Pioh dkk., 2013). Suhu tanah dipengaruhi oleh radiasi matahari yang mencapai permukaan tanah dan dipantulkan kembali ke atmosfer sedangkan sisanya diserap oleh permukaan tanah (Foth, 1984). Suhu tanah bersifat dinamis karena dipengaruhi oleh aktivitas pertukaran energi matahari melalui permukaan tanah. Suhu tanah secara langsung mempengaruhi pertumbuhan tanaman, dan juga terhadap kelembaban, aerasi, struktur, aktivitas mikrobial dan ketersediaan hara-hara tanaman. Suhu tanah juga disebut intensitas panas dalam tanah dengan satuan derajat Celcius, derajat Fahrenheit, derajat Kelvin. perlakuan jenis cover crop dan jenis biochar terhadap pengamatan suhu tanah. Pada Pengamatan suhu tanah untuk jenis perlakuan cover crop terjadi beda nyata antar perlakuan cover crop, sedangkan pada jenis biochar tidak menunjukan beda nyata antar perlakuan. Pada pengamatan suhu -1 HST tanah yang diberi perlakuan biochar Kirinyuh (B3) menghasilkan suhu tanah terendah sedangkan pada suhu $63 \mathrm{HST}$, tanah yang ditanami M. bracteata $\left(\mathrm{C}_{2}\right)$ Hasil sidik ragam (Anova) menunjukkan bahwa tidak terjadi interaksi antara 
menghasilkan suhu terendah baik pada tanah yang tidak diberi biochar $\left(\mathrm{B}_{0} \mathrm{C}_{2}\right)$ maupun yang diaplikasi biochar serbuk gergaji $\left(\mathrm{B}_{1} \mathrm{C}_{2}\right)($ Tabel 1).

Tabel 1. Suhu Tanah $\left({ }^{\circ} \mathrm{C}\right)$

\begin{tabular}{|c|c|c|c|c|c|c|}
\hline \multirow{2}{*}{ Pengamatan } & \multirow{2}{*}{ Perlakuan- } & \multicolumn{4}{|c|}{ Jenis Biochar } & \multirow[t]{2}{*}{ Rerata } \\
\hline & & B0 & B1 & B2 & B3 & \\
\hline \multirow{4}{*}{$\begin{array}{c}\text { Suhu -1 } \\
\text { HST }\end{array}$} & $\mathrm{C} 1$ & 26.5 & 27 & 28.9 & 26 & $27.10 \mathrm{~b}$ \\
\hline & $\mathrm{C} 2$ & 27 & 27.5 & 29.5 & 29.5 & $28.37 \mathrm{ba}$ \\
\hline & $\mathrm{C} 3$ & 31.5 & 28 & 28.5 & 29 & $29.25 \mathrm{a}$ \\
\hline & Rerata & $28.33 \mathrm{a}$ & $27.50 \mathrm{a}$ & $28.96 \mathrm{a}$ & $28.16 \mathrm{a}$ & $(-)$ \\
\hline \multirow{4}{*}{$\begin{array}{c}\text { Suhu } 63 \\
\text { HST }\end{array}$} & $\mathrm{C} 1$ & 24.66 & 25 & 27 & 26 & $25.66 \mathrm{ba}$ \\
\hline & $\mathrm{C} 2$ & 24 & 24 & 25 & 25 & $24.50 \mathrm{~b}$ \\
\hline & $\mathrm{C} 3$ & 25.66 & 26.33 & 27 & 27.66 & $26.66 \mathrm{a}$ \\
\hline & Rerata & $24.77 \mathrm{a}$ & $25.11 \mathrm{a}$ & $26.33 \mathrm{a}$ & $26.22 \mathrm{a}$ & $(-)$ \\
\hline
\end{tabular}

pada tingkat nyata ( $\alpha$ ) $5 \%$ menurut uji DMRT (-) tidak terjadi interaksi antar faktor

\section{Kadar Lengas Tanah}

Retensi air tanah atau kelengasan tanah yang memberikan volume air (cairan) yang tertahan didalam pori-pori sistem tanah. Air yang terdapat di dalam tanah karena ditahan atau diserap oleh masa tanah. Ketersediaan air tanah dipengaruhi oleh banyaknya curah hujan atau irigasi, evapotranspirasi dan tingginya muka air tanah (Purwowidodo, 2002)

Tabel 2. Kadar Lengas (\%)

\begin{tabular}{ccccccc}
\hline \multirow{2}{*}{ Pengamatan Perlakuan } & \multicolumn{5}{c}{ Jenis Biochar } & \multirow{2}{*}{ Rerata } \\
\cline { 2 - 6 } & & $\mathrm{B} 0$ & $\mathrm{~B} 1$ & $\mathrm{~B} 2$ & $\mathrm{~B} 3$ & \\
\hline \multirow{3}{*}{ KL -1 HST } & $19.45 \mathrm{fg}$ & $20.13 \mathrm{ef}$ & $18.53 \mathrm{~g}$ & $19.96 \mathrm{f}$ & 19.52 \\
& $\mathrm{C} 2$ & $27.23 \mathrm{a}$ & $27.66 \mathrm{a}$ & $27.34 \mathrm{a}$ & $21.87 \mathrm{bc}$ & 26.02 \\
& $\mathrm{C} 3$ & $21.13 \mathrm{~cd}$ & $22.53 \mathrm{~b}$ & $20.93 \mathrm{de}$ & $18.52 \mathrm{~g}$ & 20.77 \\
\cline { 2 - 6 } & Rerata & 22.6 & 23.44 & 22.26 & 20.12 & $(+)$ \\
\hline \multirow{3}{*}{ KL 63 HST } & $\mathrm{C} 1$ & 13.44 & 9.09 & 14.37 & 12.77 & $12.41 \mathrm{a}$ \\
& $\mathrm{C} 2$ & 7.51 & 23.37 & 9.93 & 11.23 & $13.01 \mathrm{a}$ \\
& $\mathrm{C} 3$ & 10.95 & 16.71 & 13.31 & 13.36 & $13.58 \mathrm{a}$ \\
\cline { 2 - 6 } & Rerata & $10.63 \mathrm{a}$ & $16.39 \mathrm{a}$ & $12.54 \mathrm{a}$ & $12.45 \mathrm{a}$ & $(-)$ \\
\hline
\end{tabular}

Keterangan: Angka pada baris dan kolom diikuti huruf yang sama menunjukan beda pada tingkat nyata( $\alpha) 5 \%$ menurut uji DMRT (-) tidak terjadi interaksi antar faktor

Hasil sidik ragam (Anova) menunjukkan bahwa terjadinya interaksi antara perlakuan jenis Cover crop dan jenis biochar terhadap pengamatan kadar lengas tanah-1HST. Pada lajur C2 yang dikombinasikan dengan jenis biochar memiliki nilai yang tinggi hal ini disebabkan karena pemberian air dalam jumlah yang banyak dalam masa inkubasi.Hasil sidik ragam (Anova) menunjukkan pada pengamatan kadar lengas tanah 63 HST tidak terjadinya interaksi antar faktor perlakuan. Pada pengamatan kadar lengas tanah, tanah yang diberikan perlakuan jenis biochar serbuk gergaji cenderung menghasilkan nilai yang tinggi (Tabel 2).

\section{Berat Volume Tanah}

Berat volume tanah merupakan perbandingan berat volume tanah kering daengan satuan volume tanah yang termasuk dengan volume pori-pori tanah. Berat volume merupakan petunjuk kepadatan tanah dimana semakin padat suatu tanah, maka makin tinggi berat volume artinya semakin sulit meneruskan air atau ditembus oleh akar tanaman (Hardjowigeno, 2007).

$\underline{\text { Tabel 3. Berat volume tanah }\left(\mathrm{g} / \mathrm{cm}^{3}\right)}$

\begin{tabular}{|c|c|c|c|c|c|c|}
\hline \multirow{2}{*}{ Pengamatan } & \multirow{2}{*}{ Perlakuan } & \multicolumn{4}{|c|}{ Jenis Biochar } & \multirow{2}{*}{ Rerata } \\
\hline & & B0 & B1 & B2 & B3 & \\
\hline \multirow{4}{*}{$-1 \mathrm{HST}$} & $\mathrm{C} 1$ & $1.46 \mathrm{~d}$ & $1.42 \mathrm{~d}$ & $1.54 \mathrm{bc}$ & $1.50 \mathrm{~cd}$ & 1.48 \\
\hline & $\mathrm{C} 2$ & $1.43 \mathrm{~d}$ & $1.61 \mathrm{~b}$ & $0.71 \mathrm{f}$ & $1.27 \mathrm{e}$ & 1.25 \\
\hline & $\mathrm{C} 3$ & $1.46 \mathrm{~cd}$ & $1.49 \mathrm{~cd}$ & $1.60 \mathrm{~b}$ & $1.87 \mathrm{a}$ & 1.6 \\
\hline & Rerata & 1.45 & 1.5 & 1.28 & 1.55 & $(+)$ \\
\hline \multirow{4}{*}{$63 \mathrm{HST}$} & $\mathrm{C} 1$ & 1.49 & 1.55 & 1.7 & 1.38 & $1.53 \mathrm{a}$ \\
\hline & $\mathrm{C} 2$ & 1.6 & 1.29 & 1.65 & 1.41 & $1.49 \mathrm{a}$ \\
\hline & $\mathrm{C} 3$ & 1.43 & 1.16 & 1.33 & 1.6 & $1.38 \mathrm{a}$ \\
\hline & Rerata & $1.50 \mathrm{ab}$ & $1.33 \mathrm{~b}$ & $1.56 \mathrm{a}$ & $1.46 \mathrm{ab}$ & $(-)$ \\
\hline
\end{tabular}

$\overline{\text { Keterangan :Angka pada baris dan kolom diikuti huruf yang sama menunjukan beda pada }}$ tingkat nyata $(\alpha) 5 \%$ menurut uji DMRT. (+) Terjadi interaksi antar faktor, (-) tidak terjadi interaksi antar faktor

Hasil sidik ragam Anova menunjukkan bahwa terjadinya interaksi antara perlakuan Cover crop dan jenis biochar pada pengamatan berat volume tanah -1 HST sedangkan hasil sidik ragam anova menunjukkan bahwa pada pengamatan berat volume tanah 63 HST tidak menunjukkan interaksi antar kedua faktor perlakuan (Tabel 3). Pada berat volume tanah-1 HST untuk perlakuan jenis biochar sekam padi memberikan berat volume terendah dibandingkan dengan jenis biochar lainnya. Pada pengamatan berat Volume tanah 63 HST cover crop $V$. angularis memberikan hasil berat volume tanah terendah, dan juga pada jenis biochar menunjukkan terjadinya beda nyata antar perlakuan. Jenis biochar serbuk gergaji pada pengamatan 63 HST ini menghasilkan nilai paling terendah.

\section{Tinggi Tanaman}

Menurut Sitompul dan Guritno (1995) menyatakan bahwa tinggi tanaman merupakan ukuran tanaman yang sering diamati baik sebagai indicator pertumbuhan maupun sebagai parameter yang digunakan untukmengukur pengaruh lingkungan atau perlakuan yang diterapkan.serta efesiensi penggunaan hara tanaman.

$\underline{\text { Tabel 4. Tinggi tanaman }(\mathrm{cm})}$

\begin{tabular}{|c|c|c|c|c|c|c|}
\hline \multirow[b]{2}{*}{ Pengamatan } & \multirow[b]{2}{*}{ Cover crop } & \multicolumn{4}{|c|}{ Jenis Biochar } & \multirow[b]{2}{*}{ Rerata } \\
\hline & & B0 & B1 & B2 & B3 & \\
\hline \multirow{4}{*}{$14 \mathrm{HST}$} & $\mathrm{C} 1$ & 4.67 & 3.61 & 5.16 & 3.44 & $4.22 \mathrm{a}$ \\
\hline & $\mathrm{C} 2$ & 3.33 & 3.33 & 3.72 & 2.72 & $3.27 \mathrm{~b}$ \\
\hline & C3 & 3.94 & 5.16 & 4.39 & 4.22 & $4.43 \mathrm{a}$ \\
\hline & Rerata & $3.98 \mathrm{a}$ & $4.03 \mathrm{a}$ & $4.42 \mathrm{a}$ & $3.46 \mathrm{a}$ & $(-)$ \\
\hline \multirow{4}{*}{$21 \mathrm{HST}$} & $\mathrm{C} 1$ & 6.44 & 5.83 & 6.77 & 5.33 & $6.09 \mathrm{a}$ \\
\hline & $\mathrm{C} 2$ & 5.50 & 4.94 & 5.55 & 3.94 & $4.98 \mathrm{a}$ \\
\hline & C3 & 5.72 & 7.33 & 6.83 & 5.72 & $6.40 \mathrm{a}$ \\
\hline & Rerata & $5.89 \mathrm{a}$ & $6.03 \mathrm{a}$ & $6.38 \mathrm{a}$ & $4.99 \mathrm{a}$ & $(-)$ \\
\hline \multirow{4}{*}{$28 \mathrm{HST}$} & $\mathrm{C} 1$ & 8.05 & 7.50 & 8.61 & 7.27 & $7.86 \mathrm{a}$ \\
\hline & $\mathrm{C} 2$ & 7.28 & 6.83 & 7.44 & 5.83 & $6.83 \mathrm{a}$ \\
\hline & $\mathrm{C} 3$ & 7.28 & 9.11 & 8.83 & 7.28 & $8.12 \mathrm{a}$ \\
\hline & Rerata & $7.52 \mathrm{a}$ & $7.81 \mathrm{a}$ & $8.29 \mathrm{a}$ & $6.79 \mathrm{a}$ & $(-)$ \\
\hline \multirow{4}{*}{35 HST } & $\mathrm{C} 1$ & 8.16 & 8.05 & 8.11 & 8.55 & $8.22 \mathrm{a}$ \\
\hline & $\mathrm{C} 2$ & 8.50 & 7.61 & 8.75 & 7.22 & $8.02 \mathrm{a}$ \\
\hline & $\mathrm{C} 3$ & 9.11 & 9.83 & 9.30 & 8.44 & $9.17 \mathrm{a}$ \\
\hline & Rerata & $8.59 \mathrm{a}$ & $8.50 \mathrm{a}$ & $8.72 \mathrm{a}$ & $8.07 \mathrm{a}$ & $(-)$ \\
\hline \multirow{4}{*}{$42 \mathrm{HST}$} & $\mathrm{C} 1$ & 7.33 & 8.19 & 9.66 & 8.00 & $8.29 \mathrm{~b}$ \\
\hline & $\mathrm{C} 2$ & 9.44 & 8.66 & 9.89 & 8.50 & $9.12 \mathrm{ab}$ \\
\hline & $\mathrm{C} 3$ & 10.00 & 10.61 & 9.89 & 10.00 & $10.12 \mathrm{a}$ \\
\hline & Rerata & $8.92 \mathrm{a}$ & $9.15 \mathrm{a}$ & $9.81 \mathrm{a}$ & $8.83 \mathrm{a}$ & $(-)$ \\
\hline \multirow{4}{*}{49 HST } & $\mathrm{C} 1$ & 10.55 & 12.05 & 12.25 & 11.47 & $11.58 \mathrm{~b}$ \\
\hline & $\mathrm{C} 2$ & 11.61 & 10.77 & 11.72 & 10.55 & $11.16 \mathrm{~b}$ \\
\hline & $\mathrm{C} 3$ & 12.80 & 14.08 & 14.39 & 13.94 & $13.80 \mathrm{a}$ \\
\hline & Rerata & $11.65 \mathrm{a}$ & $12.30 \mathrm{a}$ & $12.78 \mathrm{a}$ & $11.99 \mathrm{a}$ & $(-)$ \\
\hline
\end{tabular}

Keterangan: Angka yang diikuti huruf yang sama pada baris atau kolom yang sama tidak berbeda nyata menurut uji DMRT @ 5 \%. (-) tidak adanya interaksi antar faktor.

Hasil sidik ragam (Anova) menunjukkan bahwa tidak terjadi interaksi antara perlakuan jenis Cover crop dan jenis biochar terhadap pengamatan parameter tinggi tanaman. Pada Pengamatan 14 HST 35 HST 42 HST dan 49 HST untuk jenis perlakuan Cover crop terdapat beda nyata, sedangkan pengamatan ke 21 HST dan 28 HST tidak terdapat beda nyata antar perlakuan Cover crop. Pada pengamatan cover crop C3 V. angularis $\mathrm{L}$ cendrung lebih tinggi disetiap waktu pengamatan. Sedangkan jenis biochar tidak menunjukkan interaksi antar perlakuan namun tanaman cover crop yang diberi perlakuan B2 biochar sekam padi menghasilkan tinggi tanaman tertinggi pada setiap waktu pengamatan (Tabel 4) . Hal ini karena penggunaan biochar sekam padi dapat mempertahankan kesuburan tanah dan memiliki kandungan unsur hara makro yang cukup tinggi. Secara umum biochar sekam padi (B2) yang memberikan efek pertumbuhan tanaman tertinggi dibanding biochar lainnya. Cover crop $V$. angularis L yang diberi perlakuan serbuk gergaji B1 memberikan efek tinggi tanaman terbaik dibanding dengan Cover crop lainnya. Ini diduga karena jenis cover crop $V$. angularis $\mathrm{L}$ memiliki batang tipe tegak yang cenderung lebih tinggi dibanding cover crop P. lunatus dan $M$. pruriens yang memiliki batang tipe tegak namun lebih cepat bercabang (keluar sulur).

\section{Diameter Batang}

Pengukuran diameter batang dilakukan untuk mengetahui perkembangan batang bersamaan dengan pertumbuhan tanaman. Pengukuran diameter batang dilakukan di batang utama. Menurut Benyamin Lakitan (2015) menyatakan bahwa telah diketahui sejak lama bahwa hasil fotosintesis diangkut dari daun ke organ-organ lain seperti akar, batang, dan organ produktif melalui pembuluh floem. Proses pengangkutan yang terjadi akan melalui batang sehingga diameter batang akan terus meningkat untuk memperlancar dalam proses pengangkutan fotosintat dan unsur hara.

Hasil sidik ragam (Anova) menunjukkan bahwa tidak terjadi interaksi antara perlakuan jenis Cover crop dan jenis biochar terhadap pengamatan diameter batang. Pada Pengamatan 14 HST 21 HST 28 HST 35 HST dan 49 HST untuk jenis perlakuan cover crop terdapat beda nyata, sedangkan pengamatan ke 42 HST tidak terdapat beda nyata antar perlakuan Cover crop. Pada pengamatan cover crop Phaseolus Lunatus cendrung memiliki diameter batang lebih tinggi disetiap waktu pengamatan. Sedangkan jenis biochar tidak menunjukkan interaksi antar perlakuan namun tanaman cover crop yang diberi perlakuan biochar sekam padi menghasilkan tinggi tanaman tertinggi pada setiap waktu pengamatan. Pada pengamatan diameter batang 14 HST, 21 HST, dan 28 HST cover crop P. lunatus yang diberikan jenis biochar sekam padi $\left(\mathrm{B}_{2}\right)$ menghasilkan kecepatan tumbuh diameter batang lebih besar. Cover crop M. pruriens memiliki diameter batang terbesar pada 35 HST dan 42 HST yang diberikan tanpa perlakuan biochar $\left(\mathrm{B}_{0}\right)$ lebih berpengaruh untuk menghasilkan diameter batang terbesar (Tabel 5). Cover crop V. angularis L yang diberikan jenis biochar sekam padi $\left(\mathrm{B}_{2}\right)$ yang lebih berpengaruh untuk pertumbuhan 
diameter batang terbesar. Ini memperlihatkan kecepatan penambahan bobot dan ukuran sel pada diameter batang yang berbeda-beda waktu berdasarkan jenis cover cropnya. P. lunatus terlihat lebih cepat membesar batangnya di awal pertumbuhan, diikuti oleh $M$. pruriens, dan $V$. angularis $\mathrm{L}$

Tabel 5. Diameter batang $(\mathrm{mm})$

\begin{tabular}{|c|c|c|c|c|c|c|}
\hline \multirow[b]{2}{*}{ Pengamatan } & \multirow[b]{2}{*}{ Cover crop } & \multicolumn{4}{|c|}{ Jenis Biochar } & \multirow[b]{2}{*}{ Rerata } \\
\hline & & B0 & B1 & B2 & B3 & \\
\hline \multirow{4}{*}{$14 \mathrm{HST}$} & $\mathrm{C} 1$ & 0.20 & 0.18 & 0.23 & 0.20 & $0.20 \mathrm{a}$ \\
\hline & $\mathrm{C} 2$ & 0.18 & 0.19 & 0.19 & 0.16 & $0.18 \mathrm{a}$ \\
\hline & $\mathrm{C} 3$ & 0.10 & 0.14 & 0.11 & 0.13 & $0.12 \mathrm{~b}$ \\
\hline & Rerata & $0.16 \mathrm{a}$ & $0.17 \mathrm{a}$ & $0.17 \mathrm{a}$ & $0.16 \mathrm{a}$ & $(-)$ \\
\hline \multirow{4}{*}{$21 \mathrm{HST}$} & $\mathrm{C} 1$ & 0.24 & 0.22 & 0.24 & 0.22 & $0.23 \mathrm{a}$ \\
\hline & $\mathrm{C} 2$ & 0.23 & 0.22 & 0.23 & 0.20 & $0.22 \mathrm{a}$ \\
\hline & $\mathrm{C} 3$ & 0.13 & 0.16 & 0.14 & 0.14 & $0.14 \mathrm{~b}$ \\
\hline & Rerata & $0.20 \mathrm{a}$ & $0.20 \mathrm{a}$ & $0.20 \mathrm{a}$ & $0.19 \mathrm{a}$ & $(-)$ \\
\hline \multirow{4}{*}{$28 \mathrm{HST}$} & $\mathrm{C} 1$ & 0.27 & 0.24 & 0.28 & 0.24 & $0.25 \mathrm{a}$ \\
\hline & $\mathrm{C} 2$ & 0.25 & 0.24 & 0.27 & 0.23 & $0.25 \mathrm{a}$ \\
\hline & $\mathrm{C} 3$ & 0.15 & 0.17 & 0.15 & 0.16 & $0.16 \mathrm{~b}$ \\
\hline & Rerata & $0.22 \mathrm{a}$ & $0.22 \mathrm{a}$ & $0.23 \mathrm{a}$ & $0.21 \mathrm{a}$ & $(-)$ \\
\hline \multirow{4}{*}{35 HST } & $\mathrm{C} 1$ & 0.25 & 0.28 & 0.28 & 0.27 & $0.27 \mathrm{a}$ \\
\hline & $\mathrm{C} 2$ & 0.31 & 0.27 & 0.28 & 0.25 & $0.28 \mathrm{a}$ \\
\hline & $\mathrm{C} 3$ & 0.23 & 0.24 & 0.22 & 0.21 & $0.22 b$ \\
\hline & Rerata & $0.26 \mathrm{a}$ & $0.26 \mathrm{a}$ & $0.26 \mathrm{a}$ & $0.24 \mathrm{a}$ & $(-)$ \\
\hline \multirow{4}{*}{42 HST } & $\mathrm{C} 1$ & 0.28 & 0.30 & 0.29 & 0.30 & $0.29 \mathrm{a}$ \\
\hline & $\mathrm{C} 2$ & 0.32 & 0.28 & 0.29 & 0.27 & $0.29 \mathrm{a}$ \\
\hline & $\mathrm{C} 3$ & 0.29 & 0.30 & 0.29 & 0.28 & $0.29 \mathrm{a}$ \\
\hline & Rerata & $0.30 \mathrm{a}$ & $0.29 \mathrm{a}$ & $0.29 \mathrm{a}$ & $0.28 \mathrm{a}$ & $(-)$ \\
\hline \multirow{4}{*}{49 HST } & $\mathrm{C} 1$ & 0.36 & 0.38 & 0.34 & 0.36 & $0.36 \mathrm{a}$ \\
\hline & $\mathrm{C} 2$ & 0.34 & 0.29 & 0.31 & 0.29 & $0.31 \mathrm{~b}$ \\
\hline & $\mathrm{C} 3$ & 0.33 & 0.33 & 0.38 & 0.33 & $0.34 \mathrm{a}$ \\
\hline & Rerata & $0.34 \mathrm{a}$ & $0.33 \mathrm{a}$ & $0.34 \mathrm{a}$ & $0.33 \mathrm{a}$ & $(-)$ \\
\hline
\end{tabular}

Keterangan : Angka yang diikuti huruf yang sama pada baris atau kolom yang sama tidak berbeda nyata menurut uji DMRT @ 5 \%. (-) tidak adanya interaksi antar faktor.

\section{Jumlah Daun}

Daun merupakan sumber asimilat utama bagi kenaikan berat kering (Goldsworth dan Fisher, 1996). Kegiatan pertumbuhan dan hasil tanaman dipengaruhi oleh jumlah daun karena sebagai tempat kegiatan fotosintesis untuk penghasil energi yang akan diperlukan untuk proses pertumbuhan tanaman. Menurut Wijaya (2008), nitrogen mendorong pertumbuhan organorgan tanaman yang berkaitan dengan fotosintesis yaitu daun. Jumlah daun merupakan faktor utama yang menentukan kualitas pertumbuhan dan kemampuan fotosintesis suuatu tanaman.

Hasil sidik ragam (Anova) menunjukkan bahwa terjadinya interaksi antar perlakuan cover crop dan jenis biochar secara positif pada pengamatan 35 HST dan 49 HST. Hasil sidik ragam (Anova) menunjukkan bahwa tidak terjadi interaksi antara perlakuan jenis cover crop dan jenis biochar terhadap pengamatan jumlah daun. Pada Pengamatan 14 HST 21 HST 28 HST dan 42 HST untuk jenis perlakuan cover crop terdapat beda nyata. Pada pengamatan cover crop $\mathrm{C}_{2}$ Mucuna pruriens cendrung memiliki jumlah daun lebih tinggi disetiap waktu pengamatan. Sedangkan jenis biochar tidak menunjukkan interaksi antar perlakuan namun tanaman cover crop yang diberi perlakuan biochar sekam padi cendrung menghasilkan jumlah daun tertinggi hampir pada setiap waktu pengamatan (Tabel 6).

\section{Luas Daun}

Luas daun merupakan salah satu parameter analisis pertumbuhan tanaman (Sitompul dan Guritno, 1995). Pengukuran luas daun dan jumlah daun bertujuan untuk mengetahui banyaknya jumlah karbohidrat hasil fotosintesis yang menunjang pertumbuhan tanaman. Hasil sidik ragam anova menunjukkan bahwa tidak terjadinya interaksi antar perlakuan jenis cover crop dan jenis biochar terhadap luas daun. Jenis biochar tidak menunjukkan beda nyata antar perlakuan terhadap luas daun tetapi pada data tabel luas daun. Menunjukkan bahwa luas daun yang di beri perlakuan cover crop Vigna Angularis L dengan kombinasi perlakuan biochar serbuk gergaji memiliki nilai lebih tinggi dibandingkan perlakuan cover crop $P$. lunatus dan $M$. pruriens. Pada pengamatan luas daun cover crop $V$. angularis L yang diberikan jenis biochar serbuk gergaji (B1) menghasilkan nilai tertinggi dibandingkan dengan lainnya (Tabel 7).

\section{Tebal Penutupan}

Tebal penutupan tanah oleh cover crop memiliki peranan dalam melindungi tanah dari terpaan air hujan yang deras secara langsung dengan membentuk jaringan tanaman yang rapat. Ini akan melindungi tanah dari proses pemadatan tanah. Selain itu juga tebal tanaman cover crop berperan dalam menekan laju evaporasi dari tanah sehingga kelengasan tanah terjaga (Tabel 8).
Tabel 6. Jumlah daun (helai)

\begin{tabular}{|c|c|c|c|c|c|c|}
\hline \multirow{2}{*}{\multicolumn{2}{|c|}{ Pengamatan Cover crop }} & \multicolumn{4}{|c|}{ Jenis Biochar } & \multirow[b]{2}{*}{ Rerata } \\
\hline & & B0 & B1 & B2 & B3 & \\
\hline \multirow{4}{*}{14 HST } & $\mathrm{C} 1$ & 1.50 & 1.72 & 1.33 & 1.66 & $1.55 \mathrm{~b}$ \\
\hline & $\mathrm{C} 2$ & 2.16 & 1.89 & 2.83 & 1.78 & $2.16 \mathrm{a}$ \\
\hline & $\mathrm{C} 3$ & 1.61 & 1.89 & 1.66 & 1.78 & $1.73 \mathrm{~b}$ \\
\hline & Rerata & $1.75 \mathrm{a}$ & $1.83 \mathrm{a}$ & $1.94 \mathrm{a}$ & $1.74 \mathrm{a}$ & $(-)$ \\
\hline \multirow{4}{*}{$21 \mathrm{HST}$} & $\mathrm{C} 1$ & 2.11 & 2.72 & 1.88 & 2.39 & $2.27 \mathrm{~b}$ \\
\hline & $\mathrm{C} 2$ & 3.11 & 2.66 & 3.88 & 2.11 & $2.94 \mathrm{a}$ \\
\hline & $\mathrm{C} 3$ & 1.94 & 2.16 & 2.16 & 1.94 & $2.05 \mathrm{~b}$ \\
\hline & Rerata & $2.38 \mathrm{a}$ & $2.51 \mathrm{a}$ & $2.64 \mathrm{a}$ & $2.14 \mathrm{a}$ & $(-)$ \\
\hline \multirow{4}{*}{$28 \mathrm{HST}$} & $\mathrm{C} 1$ & 3.05 & 3.72 & 2.83 & 3.22 & $3.20 \mathrm{~b}$ \\
\hline & $\mathrm{C} 2$ & 4.94 & 4.61 & 5.89 & 3.72 & $4.79 \mathrm{a}$ \\
\hline & $\mathrm{C} 3$ & 2.61 & 3.33 & 3.38 & 2.99 & $3.08 \mathrm{~b}$ \\
\hline & Rerata & $3.53 \mathrm{a}$ & $3.88 \mathrm{a}$ & $4.03 \mathrm{a}$ & $3.31 \mathrm{a}$ & $(-)$ \\
\hline \multirow{4}{*}{35 HST } & $\mathrm{C} 1$ & 9.14 dce & $10.22 \mathrm{bc}$ & $8.16 \mathrm{dfe}$ & 9.16 dce & 9.17 \\
\hline & $\mathrm{C} 2$ & $12.44 \mathrm{a}$ & $11.88 \mathrm{ba}$ & $10.55 \mathrm{bc}$ & $9.50 \mathrm{dc}$ & 11.07 \\
\hline & $\mathrm{C} 3$ & $6.77 \mathrm{f}$ & $7.08 \mathrm{f}$ & $7.38 \mathrm{fe}$ & $8.03 \mathrm{dfe}$ & 7.31 \\
\hline & Rerata & 9.45 & 9.70 & 8.70 & 8.89 & $(+)$ \\
\hline \multirow{4}{*}{42 HST } & $\mathrm{C} 1$ & 11.11 & 12.05 & 10.94 & 13.44 & $11.89 \mathrm{~b}$ \\
\hline & $\mathrm{C} 2$ & 16.44 & 14.83 & 16.61 & 14.05 & $15.48 \mathrm{a}$ \\
\hline & $\mathrm{C} 3$ & 8.55 & 8.83 & 8.00 & 8.55 & $8.48 \mathrm{c}$ \\
\hline & Rerata & $12.03 \mathrm{a}$ & $11.90 \mathrm{a}$ & $11.85 \mathrm{a}$ & $12.01 \mathrm{a}$ & $(-)$ \\
\hline \multirow{4}{*}{49 HST } & C1 & $20.19 \mathrm{bac}$ & $20.25 \mathrm{bac}$ & $17.94 \mathrm{bdc}$ & $21.67 \mathrm{ba}$ & 20.01 \\
\hline & $\mathrm{C} 2$ & $20.19 a$ & $20.22 \mathrm{bac}$ & $23.66 \mathrm{a}$ & $19.72 \mathrm{bac}$ & 21.74 \\
\hline & $\mathrm{C} 3$ & $13.66 \mathrm{e}$ & $14.97 \mathrm{ed}$ & $16.77 \mathrm{edc}$ & $15.25 \mathrm{ed}$ & 15.16 \\
\hline & Rerata & 19.08 & 18.48 & 19.46 & 18.88 & $(+)$ \\
\hline
\end{tabular}

Keterangan : Angka yang diikuti huruf yang sama pada baris atau kolom yang sama tidak berbeda nyata menurut uji DMRT @ 5 \%. (-) tidak adanya interaksi antar faktor (+) terjadi interaksi antar faktor

Tabel 7. Luas daun $\left(\mathrm{cm}^{2}\right)$

\begin{tabular}{|c|c|c|c|c|c|}
\hline \multirow{2}{*}{ Cover crop } & \multicolumn{4}{|c|}{ Jenis Biochar } & \multirow{2}{*}{ Rerata } \\
\hline & $\mathrm{B} 0$ & B1 & B2 & B3 & \\
\hline $\mathrm{C} 1$ & 32.08 & 22.03 & 22.36 & 38.91 & $28.85 \mathrm{~b}$ \\
\hline $\mathrm{C} 2$ & 99.29 & 101.21 & 48.68 & 76.55 & $81.43 \mathrm{ab}$ \\
\hline $\mathrm{C} 3$ & 97.32 & 189.08 & 134.13 & 47.95 & $117.12 \mathrm{a}$ \\
\hline Rerata & $76.23 \mathrm{a}$ & $104.11 \mathrm{a}$ & $68.39 \mathrm{a}$ & $54.47 \mathrm{a}$ & $(-)$ \\
\hline
\end{tabular}

Keterangan : Angka yang diikuti huruf yang sama pada baris atau kolom yang sama tidak berbeda nyata menurut uji DMRT @ 5 \%. (-) tidak adanya interaksi antar faktor.

Tabel 8. Tebal penutupan $(\mathrm{cm})$

\begin{tabular}{ccccccc}
\hline \multirow{2}{*}{ Pengamatan } & $\begin{array}{c}\text { Cover } \\
\text { crop }\end{array}$ & \multicolumn{5}{c}{ Jenis Biochar } \\
\cline { 2 - 7 } & C1 & 23.33 & 24.55 & 26.77 & 26.22 & $25.22 \mathrm{a}$ \\
& $\mathrm{C} 2$ & 25.55 & 47.89 & 28.66 & 22.66 & $31.19 \mathrm{a}$ \\
$45 \mathrm{HST}$ & $\mathrm{C} 3$ & 29.11 & 30.66 & 29.89 & 29.78 & $29.86 \mathrm{a}$ \\
\cline { 2 - 7 } & Rerata & $26.00 \mathrm{a}$ & $34.37 \mathrm{a}$ & $28.44 \mathrm{a}$ & $26.22 \mathrm{a}$ & $(-)$ \\
\hline \multirow{5}{*}{$56 \mathrm{HST}$} & $\mathrm{C} 1$ & 26.11 & 28.89 & 29.22 & 29.11 & $28.33 \mathrm{c}$ \\
& $\mathrm{C} 2$ & 35.55 & 34.44 & 38.66 & 32.89 & $35.38 \mathrm{~b}$ \\
& $\mathrm{C} 3$ & 38.89 & 40.89 & 40.55 & 41.00 & $40.33 \mathrm{a}$ \\
\cline { 2 - 7 } & Rerata & $33.52 \mathrm{a}$ & $34.74 \mathrm{a}$ & $36.14 \mathrm{a}$ & $34.33 \mathrm{a}$ & $(-)$ \\
\hline
\end{tabular}

Keterangan : Angka yang diikuti huruf yang sama pada baris atau kolom yang sama tidak berbeda nyata menurut uji DMRT@ 5 \%. (-) tidak adanya interaksi antar faktor.

Hasil sidik ragam (Anova) menunjukkan bahwa tidak terjadi interaksi antara perlakuan jenis cover crop dan jenis biochar terhadap pengamatan tebal penutupan. Pada Pengamatan 49 HST dan 56 HST untuk jenis perlakuan Cover crop terdapat beda nyata pada pengamatan 56 HST, sedangkan pengamatan ke 49 HST tidak terdapat beda nyata antar perlakuan cover crop. Pada pengamatan 49 HST jenis Cover crop C2 M. pruriens cendrung memiliki tebal penutupan lebih baik dibandingkan jenis Cover crop lainnya. Tetapi pada pengamatan 56 HST jenis cover crop $V$. angularis L kembali lebih tinggi. Hal ini disebabkan karena tanaman ini lebih tinggi sedangkan jenis biochar tidak menunjukan interaksi antar perlakuan.

\section{Luas Penutupan}

Luas penutupan lahan merupakan ukuran panjang lebarnya Cover crop dalam menutupi permukaan tanah. Hasil sidik ragam (Anova) menunjukan bahwa terjadinya interaksi antar perlakuan Cover crop dan jenis biochar secara positif pada pengamatan luas penutupan 56 HST. Hasil sidik ragam (Anova) menunjukkan bahwa tidak terjadi interaksi antara perlakuan jenis Cover crop dan jenis biochar terhadap pengamatan luas penutupan. Pada Pengamatan 49 HST untuk jenis perlakuan Cover crop terdapat beda nyata pada pengamatan 56 HST, sedangkan pengamatan ke 49 HST dan 56 HST terdapat beda nyata antar perlakuan Cover crop. Pada pengamatan 49 HST jenis Cover crop C2 M. pruriens cendrung memiliki luas penutupan lebih baik dibandingkan jenis Cover crop lainnya. Sedangkan jenis biochar tidak menunjukan interaksi antar perlakuan (Tabel 9). 
Tabel 9. Luas penutupan (m2)

\begin{tabular}{ccccccc}
\hline \multirow{2}{*}{ Pengamatan } & \multirow{2}{*}{ Cover crop } & \multicolumn{5}{c}{ Jenis Biochar } \\
\cline { 2 - 6 } & & B0 & B1 & B2 & B3 & \\
\hline \multirow{3}{*}{$49 \mathrm{HST}$} & $\mathrm{C} 1$ & 0.25 & 0.40 & 0.31 & 0.40 & $0.34 \mathrm{~b}$ \\
& $\mathrm{C} 2$ & 0.66 & 0.78 & 0.81 & 0.61 & $0.71 \mathrm{a}$ \\
& $\mathrm{C} 3$ & 0.37 & 0.33 & 0.40 & 0.37 & $0.37 \mathrm{~b}$ \\
\cline { 2 - 7 } & Rerata & $0.43 \mathrm{a}$ & $0.50 \mathrm{a}$ & $0.51 \mathrm{a}$ & $0.46 \mathrm{a}$ & $(-)$ \\
\hline \multirow{3}{*}{$56 \mathrm{HST}$} & $\mathrm{C} 1$ & $0.52 \mathrm{~b}$ & $0.65 \mathrm{~b}$ & $0.48 \mathrm{~b}$ & $0.64 \mathrm{~b}$ & 0.57 \\
& $\mathrm{C} 2$ & $0.99 \mathrm{a}$ & $1.08 \mathrm{a}$ & $1.01 \mathrm{a}$ & $0.72 \mathrm{~b}$ & 0.95 \\
& $\mathrm{C} 3$ & $0.68 \mathrm{~b}$ & $0.58 \mathrm{~b}$ & $0.68 \mathrm{~b}$ & $0.63 \mathrm{~b}$ & 0.64 \\
\cline { 2 - 7 } & Rerata & 0.73 & 0.77 & 0.72 & 0.66 & $(+)$ \\
\hline
\end{tabular}

Keterangan: Angka yang diikuti huruf yang sama pada baris atau kolom yang sama tidak berbeda nyata menurut uji DMRT @ $5 \%$. (-) tidak adanya interaksi antar factor (+) terjadi interaksi antar faktor.

\section{Berat 100 Biji (B100)}

Berat 100 biji merupakan karakter yang menunjukan ukuran biji yang dihasilkan. Semakin tinggi berat 100 biji suatu tanaman maka kuran biji tanaman tersebut semakin besar (Tabel 10).

$\underline{\text { Tabel 10. Berat } 100 \text { Biji (gram) }}$

\begin{tabular}{cccccc}
\hline \multirow{2}{*}{ Cover crop } & \multicolumn{5}{c}{ Jenis Biochar } \\
\cline { 2 - 5 } & B0 & B1 & B2 & B3 & \\
\hline C1 & $29.93 \mathrm{~b}$ & $29.58 \mathrm{~b}$ & $36.23 \mathrm{a}$ & $35.44 \mathrm{a}$ & 32.80 \\
C2 & $0.00 \mathrm{~d}$ & $0.00 \mathrm{~d}$ & $0.00 \mathrm{~d}$ & $0.00 \mathrm{~d}$ & 0.00 \\
C3 & $8.90 \mathrm{c}$ & $8.79 \mathrm{c}$ & $8.63 \mathrm{c}$ & $7.90 \mathrm{c}$ & 8.55 \\
\hline Rerata & 12.94 & 12.79 & 14.95 & 14.45 & $(+)$ \\
\hline
\end{tabular}

Keterangan : Angka yang diikuti huruf yang sama pada baris atau kolom yang sama tidak

berbeda nyata menurut ujiDMRT@5\%.(+) adanya interaksi antar faktor.

Hasil sidik ragam (Anova) menunjukkan bahwa terjadinya interaksi antar perlakuan Cover crop dan jenis biochar secara positif pada pengamatan berat 100 biji. Jenis perlakuan Cover crop terdapat beda nyata antar perlakuan. Pada pengamatan jenis Cover crop $\mathrm{C}_{2} M$. pruriens tidak memberikan hasil dan menghasilkan nilai yang tinggi pada perlakuan jenis Cover crop P. lunatus (32.80), sedangkan pada jenis biochar tidak terdapat beda nyata antar perlakuan dan menghasilkan nilai tertinggi (14.95) pada perlakuan biochar $\mathrm{B}_{2}$ sekam padi.

\section{Berat Biji Ton Per Hektar}

Berat biji kacang ton per hektar menunjukkan hasil produksi kacang dalam luasan tiap hektar lahan. Hasil sidik ragam (Anova) menunjukkan bahwa tidak terjadi interaksi antara perlakuan jenis cover crop dan jenis biochar terhadap pengamatan ton per hektar. Pada Pengamatan ton per hektar untuk jenis perlakuan cover crop terdapat beda nyata antar perlakuan, sedangkan Pada pengamatan jenis cover crop $\mathrm{C}_{2}$ Mucuna pruriens tidak memberikan hasil dan pada $\mathrm{C}_{3} V$. angularis $\mathrm{L}$ cendrung memiliki nilai ton per hektar lebih baik dibandingkan jenis cover crop $\mathrm{C}_{1} P$. lunatus. Pada jenis biochar tidak menunjukan interaksi antar perlakuan (Tabel 11).

Tabel 11. Berat biji Ton Per Hektar (t/Ha)

\begin{tabular}{|c|c|c|c|c|c|}
\hline \multirow{2}{*}{ Cover crop } & \multicolumn{4}{|c|}{ Jenis Biochar } & \multirow{2}{*}{ Rerata } \\
\hline & B0 & $\mathrm{B} 1$ & B2 & B3 & \\
\hline $\mathrm{C} 1$ & 0.11 & 0.14 & 0.10 & 0.13 & $0.12 \mathrm{~b}$ \\
\hline $\mathrm{C} 2$ & 0.00 & 0.00 & 0.00 & 0.00 & $0.00 \mathrm{c}$ \\
\hline $\mathrm{C} 3$ & 0.26 & 0.22 & 0.18 & 0.17 & $0.21 \mathrm{a}$ \\
\hline Rerata & $0.12 \mathrm{a}$ & $0.12 \mathrm{a}$ & $0.09 \mathrm{a}$ & $0.10 \mathrm{a}$ & $(-)$ \\
\hline
\end{tabular}

Keterangan : Angka yang diikuti huruf yang sama pada baris atau kolom yang sama tidak berbeda nyata menurut uji DMRT@ 5 \%. (-) tidak adanya interaksi antar faktor.

\section{Bintil Akar Efektif}

Seperti diketahui bahwa tanaman leguminosa mempunyai bintil akar yang merupakan petunjuk adanya simbiosis antara akar tanaman dengan bakteri bintil akar yang menambat nitrogen bebas dari atmosfer. Ciri bintil akar efektif adalah bintil akar masih segar dan berisi cairan kemerahan (Tabel 12).

\section{Tabel 12. Bintil Akar Efektif}

\begin{tabular}{|c|c|c|c|c|c|}
\hline \multirow{2}{*}{ Cover crop } & \multicolumn{4}{|c|}{ Jenis Biochar } & \multirow{2}{*}{ Rerata } \\
\hline & $\mathrm{B} 0$ & $\mathrm{~B} 1$ & $\mathrm{~B} 2$ & B3 & \\
\hline $\mathrm{C} 1$ & 16.75 & 10.00 & 7.25 & 11.25 & $11.31 \mathrm{~b}$ \\
\hline $\mathrm{C} 2$ & 5.00 & 10.75 & 8.00 & 7.50 & $7.81 \mathrm{~b}$ \\
\hline $\mathrm{C} 3$ & 25.75 & 11.50 & 31.00 & 21.00 & $22.31 \mathrm{a}$ \\
\hline Rerata & $15.83 \mathrm{a}$ & $10.75 \mathrm{a}$ & $15.41 \mathrm{a}$ & $13.25 \mathrm{a}$ & $(-)$ \\
\hline
\end{tabular}

Keterangan: Angka yang diikuti huruf yang sama pada baris atau kolom yang sama tidak berbeda nyata menurut uji DMRT@5\%. (-) tidak adanya interaksi antar faktor.

Hasil sidik ragam (Anova) menunjukkan bahwa tidak terjadi interaksi antara perlakuan jenis Cover crop dan jenis biochar terhadap pengamatan bintil akar efektif. Pada Pengamatan bintil akar efektif untuk jenis perlakuan cover crop terdapat beda nyata antar perlakuan, sedangkan Pada pengamatan jenis cover crop pada $\mathrm{C}_{3} V$. angularis L. cendrung memiliki nilai bintil akar efektif lebih baik dibandingkan jenis Cover crop lainnya. Pada jenis biochar tidak menunjukan interaksi antar perlakuan.

\section{Berat Kering Brangkasan Per Hektar (gram)}

Berat kering brangkasan merupakan indicator pertumbuhan tanaman karena berat kering tanaman merupakan hasil akumulasi asimilat tanaman yang diperoleh dari total pertumbuhan dan perkembangan tanaman selama masa hidupnya semakin besar berat kering brangkasan berarti semakin baik pertumbuhan dan perkembangan tanaman (Sitompul dan Guritno, 1995)

\section{Tabel 13. Berat Kering Brangkasan Per Hektar}

\begin{tabular}{|c|c|c|c|c|c|}
\hline \multirow{2}{*}{ Cover crop } & \multicolumn{4}{|c|}{ Jenis Biochar } & \multirow{2}{*}{ Rerata } \\
\hline & B0 & $\mathrm{B} 1$ & B2 & B3 & \\
\hline $\mathrm{C} 1$ & 0.01 & 0.01 & 0.01 & 0.01 & $0.01 \mathrm{~b}$ \\
\hline $\mathrm{C} 2$ & 0.01 & 0.02 & 0.02 & 0.01 & $0.02 \mathrm{a}$ \\
\hline $\mathrm{C} 3$ & 0.01 & 0.01 & 0.01 & 0.00 & $0.01 \mathrm{~b}$ \\
\hline Rerata & $0.01 \mathrm{a}$ & $0.01 \mathrm{a}$ & $0.01 \mathrm{a}$ & $0.01 \mathrm{a}$ & $(-)$ \\
\hline
\end{tabular}

Keterangan: Angka yang diikuti huruf yang sama pada baris atau kolom yang sama tidak berbeda nyata menurut uji DMRT@ 5 \%. (-) tidak adanya interaksi antar faktor.

Hasil sidik ragam (Anova) menunjukkan bahwa tidak terjadi interaksi antara perlakuan jenis cover crop dan jenis biochar terhadap pengamatan berat kering brangkasan per hektar (Tabel 13). Pada pengamatan berat kering brangkasan per hektar untuk jenis perlakuan cover crop terdapat beda nyata antar perlakuan sedangkan pada jenis biochar tidak menunjukan interaksi antar perlakuan lainnya.

\subsection{Pembahasan}

Hasil penelitian menunjukkan bahwa pada perlakuan jenis biochar dan jenis cover crop terhadap paramater lingkungan suhu tanah tidak terjadinya interaksi antar faktor perlakuan. Tanah yang diberi perlakuan jenis biochar sekam padi dapat meningkatkan kapasitas menahan air sehingga mengurangi run off dan pencucian unsur hara. Selain itu biochar juga dapat memperbaiki struktur porositas dan formasi agregat tanah (Southavong, 2012). Suhu tanah dipengaruhi oleh radiasi sinar matahari yang mencapai permukaan tanah. Panas matahari secara perlahan akan dihantar sehingga mempengaruhi suhu tanah di lapisan tanah yang lebih dalam. Data pada tabel 1 menunjukkan bahwa pada pengamatan -1 HST suhu tanah berkisar $26-31.5^{\circ} \mathrm{C}$, semantara pada $63 \mathrm{HST}$ suhu tanah berkisar pada rentang $24-27.66^{\circ} \mathrm{C}$. Pengamatan pada 63 HST menunjukkan bahwa $M$. Bracteata mampu menjaga suhu tanah pada rentang $24-25^{\circ} \mathrm{C}$. Kemampuan menjaga suhu tanah ini diduga disebabkan oleh jumlah daun yang banyak dan luas tutupan yang besar.

Ini sejalan dengan pendapat Foth (1984) bahwa fluktuasi suhu tanah dapat dikurangi dengan penggunaan mulsa dan berbagai macam naungan yang mampu menghalangi radiasi matahari. Pada parameter kadar lengas tanah yang diberikan perlakuan cover crop $V$. Angularis L. memberikan hasil kadar lengas tanah yang baik hal ini dikarenakan $V$. angularis $\mathrm{L}$ memiliki akar yang panjang dan memiliki akar yang halus, sebagian akarnya membentuk bintilbintil yang merupakan sumber unsur nitrogen dan sebagian lagi tanpa nodula yang berfungsi menyerap air dan unsur hara (Irfan, 1999), sedangkan tanah yang diberi perlakuan biochar Kirinyuh mampu meningkatkan kadar lengas tanah hal ini disebabkan karena biochar Kirinyuh memiliki potensi sebagai bahan pembenah tanah dimana berfungsi untuk meningkatkan $\mathrm{pH}$, menurunkan bobot isi, meningkatkan pori total, serta menambah unsur hara (Suryantini, 2009). Menurut Sitompul dan Guritno (1995) tinggi tanaman merupakan ukuran tanaman yang sering diamati baik sebagai indikator pertumbuhan maupun sebagai parameter yang digunakan untuk mengukur pengaruh lingkungan atau perlakuan yang diterapkan.

Hasil penelitian ini menunjukan bahwa tidak terjadi interaksi antar faktor perlakuan terhadap tinggi tanaman. Pada parameter ini cover crop $V$. Angularis L memberikan hasil tinggi tanaman yang paling baik dibandingkan dengan $P$. lunatus dan $M$. pruriens. Perlakuan biochar sekam padi memberikan pertumbuhan tinggi tanaman yang baik. Hal ini karena biochar sekam padi meningkatkan ketersediaan N, P, dan K dalam tanah. Salah satu upaya untuk meningkatkan ketersediaan unsur hara di dalam tanah yakni dengan menggunakan biochar (Lehmann dan Joseph, 2009). Diameter batang merupakan garis lurus yang menghubungkan dua titik ditepi batang dan melalui sumbu batang dan lingkaran batang merupakan panjang garis busur yang melingkar batang (Enge, 2011). Pada pengamatan diameter batang dalam penelitian ini cover crop P. Lunatus memberikan hasil diameter batang yang lebih besar dibandingkan dengan jenis cover crop $M$.pruriens dan $V$. Angularis L. Hal ini karena $P$. lunatus pertumbuhannya sangat cepat dan memiliki kemampuan adaptasi secara baik di daerah tropis khususnya yang tanahnya kurang subur dan berkelembaban tinggi (Yaguiu, 2003).

Di sisi lain tanah yang diberi perlakuan biochar sekam padi juga mampu memberikan pertumbuhan batang cover crop dengan baik. Hal ini disebabkan karena ketersediaan $\mathrm{N}, \mathrm{P}, \mathrm{K}$. dan ketersediaan unsur hara di dalam tanah (Lehmann dan Joseph, 2009). Pada pengamatan jumlah daun 14 HST, 21 hst dan 28 HST jenis cover crop $M$. pruriens yang diberikan perlakuan jenis biochar sekam padi $\left(\mathrm{B}_{2}\right)$ menghasilkan jumlah daun terbanyak dan pada pengamatan $35 \mathrm{HST}$, M. pruriens tanpa perlakuan biochar $\left(\mathrm{C}_{2} \mathrm{~B}_{0}\right)$ yang memiliki jumlah daun terbanyak dibandingkan dengan perlakuan cover crop yang diberikan biochar lainnya. Pada 42 hst dan 49 HST M. Pruriens yang diberikan biochar sekam padi $\left(B_{2}\right)$ kembali menghasilkan jumlah daun terbanyak. $M$. pruriens diketahui mempunyai pertumbuhan yang cepat dan dapat berkompetisi dengan pertumbuhan gulma (Laksono, 2016). Jumlah daun, 
luas tutupan, dan berat kering brangkasan $M$. pruriens menunjukkan bahwa $M$. pruriens mampu berperan sebagai tanaman penutup tanah di daerah lahan kering. Penambahan bahan organik $\left(\mathrm{B}_{2}\right)$ menciptakan kondisi pertumbuhan yang optimal sehingga meningkatkan jumlah pembentukan daun. Pada parameter jumlah daun cover crop $M$. pruriens memberikan hasil daun terbanyak dibandingkan dengan cover crop lainnya. Hal ini disebabkan karena tanaman $M$. pruriens memiliki pertumbuhan cepat, tahan terhadap naungan dapat berkompetisi dengan pertumbuhan gulma, memiliki kemampuan fiksasi $\mathrm{N}$ yang tinggi dan produksi biomassa tinggi (Laksono dkk, 2016). Sedangkan tanah yang diberi perlakuan biochar sekam padi memberikan efek yang paling baik bagi pertumbuhan cover crop M. pruriens.

Hal ini karena pemberian biochar sekam padi ke dalam tanah dapat menurunkan kehilangan hara (Major dkk., 2012). Pada parameter luas penutupan cover crop $M$. pruriens memberikan penutupan tanah yang lebih luas karena memiliki perakaran yang dalam mampu menyerap air dan unsur hara lebih baik sehingga pertumbuhan tajuknya lebih baik. Dengan demikian dapat memperbaiki sifat fisik tanah dan menghasilkan serasah yang tinggi sebagai humus yang terurai lambat, sehingga menambah kesuburan tanah dapat menambat unsur N bebas dari udara (Harahap dan Subroto, 2002). Selanjutnya tanah yang diberi perlakuan biochar serbuk gergaji menunjang pertumbuhan tajuk tanaman disebabkan biochar serbuk gergaji merupakan sumber $\mathrm{K}$ yang dibutuhkan tanaman dan tidak mudah menggumpal atau memadat sehingga akar tanaman dapat tumbuh dengan sempurna (Subagyo, 2004). Pada parameter tebal penutupan cover crop $V$. angularis $\mathrm{L}$ memberikan hasil ketebalan penutup Cover crop terbaik dibandingkan dengan Cover crop lainnya. Sedangkan tanah yang diberi perlakuan jenis biochar sekam padi memberikan pertumbuhan tajuk yang penutupannya lebih tebal karena biochar sekam padi mampu meningkatkan ketersediaan $\mathrm{N}, \mathrm{P}$, dan $\mathrm{K}$ dalam tanah (Lehmann dan Joseph, 2009). Dengan penambahan biochar sekam Padi akan meningkatkan kapasitas menahan air tanah. Jika kapasitas menahan air ditingkatkan maka ketersediaan air tanaman menjadi meningkat.

Pengaruh signifikan yang diberikan biochar terhadap kapasitas retensi air tanah juga telah dilaporkan Beck dkk (2011). Parameter berat 100 biji $P$. lunatus memiliki nilai yang tinggi dibanding $V$. angulari $s \mathrm{~L}$, namun pada parameter berat biji ton per hektar menunjukkan hasil yang berbanding terbalik. hal ini dikarenakan biji $P$. lunatus yang berukuran lebih besar dibanding ukuran $V$. angularis $\mathrm{L}$. Produktivitas $V$. angularis $\mathrm{L}$ yang lebih tinggi (Tabel 11) dibandingkan P. lunatus diduga karena jumlah biji $V$. anglaris $\mathrm{L}$ yang lebih banyak. Jumlah biji yang banyak dipengaruhi oleh kemampuan bintil akar efektif tanaman dalam mengikat nitrogen (Tabel 12). Suplai nitrogen dan luas daun (Tabel 7) yang besar berkaitan dengan kemampuan melakukan fotosintesis mengakibatkan $V$. angularis $\mathrm{L}$ mengakumulasikan hasil fotosintat yang banyak ke biji tanaman.

\section{Simpulan}

Berdasarkan hasil penelitian ini disimpulkan bahwa; Legume cover crop M. pruriens terbaik dalam luas penutupan tanah dan memberikan suhu tanah yang baik dan dapat meningkatkan kadar lengas tanah. Produktivitas legume cover crop $V$. angularis L. memberikan produktivitas terbaik sedangkan $M$. pruriens belum berproduksi tetapi baik luas penutupan dan ketebalan yang mana sangat baik digunakan sebagai tanaman penutup tanah.

\section{Pustaka}

Beck, D.A.,. Johnson, G.R. and Spolek, G.A. 2011. Amending green roof soil with biochar to affect runoff water quantity and quality. Environmental Pollution 159, 2111-2118

Benyamin Lakitan. 2015. Dasar -dasar Fisiologi Tanaman. Rajawali Press. Jakarta. $169 \mathrm{~h}$

Enge, H. 2011. Diktat Ilmu Ukur Kayu.

Foth, H.D. 1984. Dasar- Dasar Ilmu Tanah. Terjemahan Purbayanti, E. D. Dwi R. L. Rayahayuning T. Gajah Mada University Press. Yogayakarta.

Glaser, B., J. Lehmann, and W. Zech. 2002. Ameliorating physical and chemical properties of highly weathered soils in the tropics with charcoal: A review. Biol. Fertil. Soils 35:219-230

Goldsworthy, P. R dalam Fisher, N. M. 6 dan P. R. Goldsworty., 1996. Jagung Tropik dalam Fisiologi Tanaman Budidaya Tropik.UGMPress, Yogyakarta. Hal 281-315.

Harahap, I.Y dan Subroto. 2002. "Penggunaan Kacang Penutup Tanah Mucuna bracteata pada pertanaman kelapa sawit". Warta Pusat Penelitian Kelapa Sawit. Medan: Warta Pusat Penelitian Kelapa Sawit 10 (1):16.

Hardjowigeno, S. 2007. Ilmu Tanah. Jakarta: Akademika Pressindo.296 Halaman

Irfan, 1999. Bertanam Kacang Sayuran. Jakarta: Penebar Swadaya.

Laksono, P.B., A. Wachjar, Supijatno. 2016. Pertumbuhan Mucuna bracteata DC. pada Berbagai Waktu Inokulasi dan Dosis Inokulan. Jurnal Agronomi Indonesia. 44 (1) : 104-110.

Lehmann, J. and S. Joseph. 2009. Biochar for environmental management. Earthscan: 127-143. United Kingdom.

Major, J. 2010. Soil Improvement from Application of Biochar. International Biochar Inititive. IBI Research Summaries are intended to provide answers about biochar science for the general public. Soil Improvement. 8 June 2010.
Pioh DD. Rayes L. Polii B. Hakim L. 2013. Analisis suhu tanah di kawasan wisata alam Danau Linow Kota Tomohon Sulawesi Utara. J Ind Tour Dev Std. 1(2).

Purwowidodo. 2002. Panduan Praktikum Konservasi Tanah dan Air. Laboratorium Pengaruh Hutan. Edisi 3. Jurusan Manajemen Hutan. Bogor: Fakultas Kehutanan IPB.

Purwono dan R. Hartono, 2011. Bertanam jagung unggul. Penebar Swadaya. Jakarta. 64 hal.

Setiawan, E. 2009. Kearifan Lokal Pola Tanam Tumpangsari di Jawa Timur. Fakultas Pertanian. Universitas Trunojoyo . J.Agrovigor. 2 (2): 79-89.

Sitompul dan B. Guritno. 1995.Analisis Pertumbuhan Tanaman. UGM Press. Yogyakarta

Southavong, S. 2012. Effect of soil amender (biochar or charcoal) andbiodigester effluent on growth and yield of water spinach, rice and on soilfertility.Thesis in Agricultural Sciences Animal Husbandry.Can ThoUniversity

Subagyo, H., N. Suharta, dan A.B. Siswanto. 2004. Tanah-tanah pertanian di Indonesia. Sumberdaya Lahan Indonesia dan Pengelolaannya. Pusat Penelitian dan Pengembangan Tanah dan Agroklimat, Bogor.

Suryantini, A. Tutik, P.I., A. Masulili. Pengelolaan Limbah Padi dan Biomassa Tumbuhan Liar Chromolaena odorata untuk Meningkatkan Produktivitas Padi (Oriza sativa L. ) di Tanah Sulfat Masam. Laporan Akhir Penelitian Hibah Kompetitif, Universitas Panca Bhakti, Pontianak (2009).

Yaguiu. 2003. Grouping of Brazilian accesses of lima beans (Phaseolus lunatus L.) according to SDS-PAGE patterns and morphological characters Acta Scientiarum: Agronomy Maringá, v. 25, n. 1, p. 7-12, 2003

Wijaya, K. A. 2008. Nutrisi Tanaman. Prestasi Pustaka. Jakarta. 115 hlm. 